International Journal of Multidisciplinary Education and Research

ISSN: 2455-4588

Impact Factor: RJIF 5.12

www.educationjournal.in

Volume 3; Issue 2; March 2018; Page No. 48-51

\title{
Development of learning strategy based on KWL (Know - Want to Know - Learnid) strategy
}

\author{
Pauzi Akbar, Idawati Butar-Butar \\ University of Muslim Nusantara Al-wasliyah, Indonesia
}

\begin{abstract}
Problems in this research is how the level of students' ability to read class XI SMA Negeri 1 Kota Pinang Year Learning 2017/2018 after following the strategy-based learning strategy KWL (Know - Want to Know - Learning)? The purpose of this study is to describe the level of students' ability to read class XI SMA Negeri 1 Kota Pinang Year Learning 2017/2018 after following the strategy-based learning strategy KWL. Research subject to product learning strategy of reading ability is validator. In addition, the subject of this research is the students of grade XI SMA Negeri 1 Kota Pinang. The object of research on this research is learning strategy of reading ability that is KWL strategy which implemented in class XI student of SMA Negeri 1 Kota Pinang Learning Year 2017/2018. The method used in the research is the research development method (Research \& Development). Instruments used to collect data are questionnaires, tests and observations. The results of this study indicate that the development of learning strategy based on learning KWL strategy is effective in improving students' reading ability of class XI SMA Negeri 1 Kota Pinang Year Learning 2017/2018, where the average value obtained by students before the development process that is equal to 17,88 which is at less category. Furthermore, after development process of learning strategy of reading based on KWL strategy and implementation of learning strategy of reading based on KWL strategy shows that the result of the average score that is owned by students is 31,41 . Thus, the average level of reading ability of grade XI students SMA Negeri 1 Kota Pinang Year Learning 2017/2018 after the development of learning strategy of reading based on KWL strategy is in high category.
\end{abstract}

Keywords: development of learning strategy, reading, KWL

\section{Introduction}

Reading ability is the main capital in the learning process. With the provision of reading skills, children will gain knowledge and simplify his mindset to think more critical. Through reading learning, students are expected to provide appropriate responses to information that has been read. In addition, reading can also be the key to opening knowledge. Success in reading is very important for learners in the context of developing academic ability, skill, and intelligence (Carnine in Sudiana 2007:2) [12]. Meanwhile, Yunus (in Sudiana 2007:2) ${ }^{[12]}$ does not doubt that reading is the key to a student's success. For students reading is an important factor in all teaching efforts.

Culture read in Indonesia as faced in a blurred mirror, blurred and unclear. In the view of Alfathri Adlin cited Zuchdi (2008: 13) ${ }^{[21]}$, the people of Indonesia is a society that most of the population is a praliteration society that was hit by a wave of posliterasi (television, internet, mobile phones, and so on). The prealitarian mentality is more dominant in the tradition of chats. The contact with various posliterasi media without directions leads to the attitude of using sophisticated technology limited to unclear chat. Such conditions are more problematic with negative and unproductive influx of posliteration waves. The above is a barrier to the development of reading culture.

Through reading activities, the reader can respond in the form of acceptance, rejection, and criticism of what has been read. In the process of reading, the reader engages in a contumptive manner in absorbing and understanding the reading material.
Thus, reading activity is able to stimulate the active mental and physical functions of a person. Further Johnson and Pearson (in Zuchdi, 2008:23) ${ }^{[21]}$ states that the factors that affect the competence of reading can be divided into two kinds, namely that exist within and outside the reader. Factors within the reader include linguistic abilities, interest (how much the reader cares about the reading it faces), motivation (how much readers care about reading assignments or general feelings about reading and school), and a collection of reading skills (how well readers can read).

Through reading activities, the reader can respond in the form of acceptance, rejection, and criticism of what has been read. In the process of reading, the reader engages in a contumptive manner in absorbing and understanding the reading material. Thus, reading activity is able to stimulate the active mental and physical functions of a person. Further Johnson and Pearson (in Zuchdi, 2008:23) ${ }^{[21]}$ states that the factors that affect the competence of reading can be divided into two kinds, namely that exist within and outside the reader. Factors within the reader include linguistic abilities, interest (how much the reader cares about the reading it faces), motivation (how much readers care about reading assignments or general feelings about reading and school), and a collection of reading skills (how well readers can read).

Based on the results of initial observations that researchers have done in class XI SMA Negeri 1 Kota Pinang, North Sumatra province, Indonesia, it turns out the learning process is still conventional. Lecture and assignment methods still dominate in the learning process, so students tend to be 
passive and lazy to do the task given by the teacher. Conditions that also affect student achievement becomes low. The average grade in the material understands the content of discourse is 59.20 still below the minimum completeness criterion (KKM) that is 70. Students of class XI SMA Negeri 1 Kota Pinang Year Learning 2017/2018 still have difficulty in understanding one contents of discourse. This is obvious when students are asked to retell the contents of the discourse they have read, most students are unable to tell. The number of students who are a lot of 38 people is one of the causes of learning becomes less conducive. Therefore, teachers are required to develop creative innovative learning to cope with problems faced by students.

To achieve this a teacher must be able to prepare appropriate learning strategies in reading learning. According to Uno (2011:45) learning strategies are things that need to be considered teachers in the learning process. There are at least three types of strategies related to learning, namely (1) learning organizing strategies, (2) learning delivery strategies, and (3) learning management strategies. The description of the teaching delivery strategy emphasizes what media is used to convey the teaching, what learning activities the students are doing, and in what learning structure of learning. The management strategy emphasizes scheduling the use of every component of the organizing strategy and teaching delivery strategy, as well as making notes on student learning progress. More than that, to accompany the state of life that continues to grow, especially the world of education, it takes more than the efforts made before, namely the effort of development of the learning strategy itself. Therefore, in this research will be discussed about the development of learning strategy of reading, which in the world of education today is very necessary, so there needs to be an in-depth study of this matter.

\section{Method}

Research subject to product learning strategy of reading ability is validator. Assessment is done by filling the validation sheet that has been provided, which became the validator in this study is an expert lecturer. In addition, the subject of this research is the students of class XI SMA Negeri 1 Kota Pinang, North Sumatra province, Indonesia. The object of research on this research is learning strategy of reading ability, that is KWL strategy which implemented in class XI student SMA Negeri 1 Kota Pinang Year Learning 2017/2018. Instruments used to obtain research data using non-test instruments and test instruments. Nontes instruments include observations and questionnaires addressed to students, while test instruments are used to measure students' reading level. Researchers use nontest instruments as data gathering tools and guidelines in analyzing the learning activities undertaken by teachers and students. In addition nontes instrument is also useful to observe every interaction that occurs during the learning process in the class progresses, get data about the factors of reading students and know the needs of students in the development of learning strategies reading. The final product produced in this study was also assessed using nontes instruments as validation performed by expert lecturers. There are two instruments used nontes are observation and questionnaire (questionnaire).
Data collection techniques in this study using observation techniques, questionnaires and validation sheet.Teknik data collection in the form of observations made at the beginning of the study to obtain data on the use of learning strategies used by teachers during the teaching and learning process. In this study the questionnaire type used in the form of closed questionnaire is in the form of questions or statements with a number of specific answers as an option. Questionnaire given to all students who become respondents. Questionnaire given to the students is useful to reveal data about the factor of reading students, in this case the intended reading factor is the reading habit of students. The Validation Sheet contains an explanation given by the validator on the feasibility of a reading ability strategy developed by the researcher.

\section{Result}

Based on the result of research, it can be concluded that the most scores obtained by students are in the interval class $17-$ 19 that is 13 students $(36.11 \%)$, then in the interval $14-16$ that is 9 students $(25 \%)$, in interval class $20-22$ as many as 6 students $(16.67 \%)$, in class interval $23-25$ that is as many as 4 students $(11,11 \%)$, while the lowest score is in interval class $11-13$ and $8-10$ that is 2 students $(5.56 \%)$.

The calculation results explain that the average value of reading ability obtained by students is 17.88 . Therefore, the average level of reading ability of students in grade XI SMA Negeri 1 Kota Pinang Year Learning 2017/2018 can be said less. This is evident from 36 students, obtained an average value of 17.88 and the category is less. The results of this test analysis are not in line with the results of the questionnaire development needs that are categorized high.

Based on this, the researchers concluded that the ability to read students need to be improved because it is in the category less. This is the reason that researchers use in planning to develop a strategy based learning KWL strategy in improving students' reading ability in grade XI SMA Negeri 1 Kota Pinang Year Learning 2017/2018.

After KWL learning strategy is implemented, the next step is evaluation by giving the test. The researcher assessed the reading ability test after the development of KWL learning strategy. Assessment of test results is done based on predetermined criteria.

From the results of reading ability tests obtained, it is known that the lowest score obtained by students is 25 and the highest score obtained by students is 36 , with an overall average value of 31.41. If the average score is consulted with the assessment criteria, then an average of 31.41 is at very high criteria. Thus, it is concluded that students' reading ability of grade XI SMA Negeri 1 Kota Pinang Year Learning 2017/2018 after development of learning strategy of reading based on KWL strategy is in very high category.

Based on the results of research can be concluded that the most scores obtained by students are in the interval class 3133 are as many as 12 students $(33.33 \%)$, then in the interval class 34-36 that is as many as 11 students $(30.56 \%)$, in the interval class 28-30 are as many as 9 students (25\%), while the lowest score is in the classroom interval $25-27$ that is 4 students $(11,11 \%)$.

The calculation results explain that the average score of reading ability obtained by students is 31.41 . Therefore, the 
average level of reading ability of grade XI students of SMA Negeri 1 Kota Pinang in the Year of Learning 2017/2018 after the development of learning strategy of reading based on KWL strategy can be said very high.

Berdasarkan uraian hasil uji coba produk terhadap siswa maka dapat diperoleh data skor rata-rata pada tabel 1

Table 1: Results of Module Trial Assessment

\begin{tabular}{|c|c|c|}
\hline Aspect Rating & Average & Category \\
\hline Feasibility of Filling & 4,5 & Very Good \\
\hline Eligibility & 4,7 & Very Good \\
\hline Feasibility of Presentation & 4,6 & Very Good \\
\hline Channel Feasibility & 4,7 & Very Good \\
\hline Average Score & 4,6 & Very Good \\
\hline
\end{tabular}

Based on table 1 it can be stated that the average score obtained in the module test gets a score of $4.6 \%$ which fall into very good category. Thus, it can be concluded that the learning strategy KWL worthy to be used as a learning strategy in improving the ability of reading students of class XI SMA Negeri 1 Kota Pinang Year Learning 2017/2018, this is evidenced by the responses given by students after learning strategies KWL trial is in the category of very good.

\section{Discussion}

The results showed that the results of reading ability tests included in the category less. The problem indicates that students need individual learning strategies that are useful for improving their reading skills. To solve the problem, the researcher uses questionnaire to analyze the need of development of learning strategy of reading to know the needs of students in learning strategy module to be developed.

The students' reading ability before the development of learning strategy based on reading KWL strategy described above is the basis used by the researcher to develop the learning strategy of reading. Researchers develop learning strategies to read based on data that has been found that is the result of questionnaire analysis needs and results of reading ability tests. The development of the strategy is called the KWL strategy. The following elaboration strategies that have been developed and developed based on the conditions and needs of students of class XI SMA Negeri 1 Kota Pinang Year Learning 2017/2018, which consists of several steps that must be applied to students during the learning process, namely:

1. Students form groups with 4 members per group.

2. Students brainstorm about the text entitled "Valentines" Mother and Piece of Bread "with teacher guidance. Then write the results of brainstorming on the K-W-L column sheet K (Know step).

3. Students ask questions about things to be learned and learned from the text titled Valentines "Mother and Piece of Bread" and then write the question on the K-W-L column sheet W (step Want to know).

4. Students read the text entitled Love "Mother and Piece of Bread"

5. Students examine the questions that have been answered and write down the information learned from the results of reading the text on the work sheet K-W-L column $\mathrm{L}$ (Learned step).
6. Students discuss to classify various information obtained from reading into several categories of information.

7. After writing several categories along with other explanatory information, students develop in the form of mapping by placing the title of the text as its center

8. After the mapping stage, students summarize the text of "Emak and Piece roti" affection in the order of their structure by using good and correct Indonesian.

9. Students discuss to do the exercises given by the teacher.

10. Students write the results of the discussions that have been done in colored paper.

The purpose of this strategy is that students are able to define the main idea, be able to choose the important points, able to find information, able to summarize the reading, able to distinguish fact from opinion and able to conclude the contents of reading. In addition, this strategy was developed to improve students' reading ability to be higher. The researcher makes the development of learning strategy of reading by considering some aspects such as student's need in the use of learning strategy, situation and condition, learning resource used.

Based on the results of the calculations that researchers have done, shows that the average value obtained by students before the process of developing learning strategies based on KWL strategy is 17.88 . Thus, the average level of reading ability of grade XI students of SMA Negeri 1 Kota Pinang in Learning Year 2017/2018 before the process of developing learning strategy based on KWL strategy can be said less.

Furthermore, after development process of learning strategy of reading based on KWL strategy and implementation of learning strategy of reading based on KWL strategy shows that the result of the average score that is owned by students is 31,41 . Thus, the average level of reading ability of students of grade XI SMA Negeri 1 Kota Pinang Year Learning 2017/2018 after the development of learning strategy based on reading strategy KWL can be said high. From these results, it can be seen that there is an increase in students' reading ability before the process of developing learning strategy based on KWL strategy is in the category of less increase to be high after the process of developing learning strategy based on KWL strategy in class XI students SMA Negeri 1 Kota Pinang Learning Year 2017/2018.

The results of this study are also supported by the validation test conducted by Prof. Dr. Khairil Ansari showed that on the content feasibility aspect obtained the average score of validation of 3.5 with good category. Then on the aspect of language feasibility obtained the average score validation of 4 with good category and on the aspect of the feasibility of the content diketahi average validation score is 4 with good category. Thus, it can be concluded that learning strategy of reading based on KWL strategy is feasible to be used in improving students' reading ability in grade XI SMA Negeri 1 Kota Pinang Year Learning 2017/2018.

In addition, the results of this study are also supported by the responses expressed by students after the test of the product obtained an average score of $4.6 \%$ which fall into the category very well. Thus, it can be concluded that the strategy of learning to read based on KWL strategy is appropriate to be 
used as a learning strategy to read in the students of grade XI SMA Negeri 1 Kota Pinang Tahun of Learning 2017/2018.

\section{Conclusion}

1. The process of developing learning strategies based on reading KWL strategy in improving students' reading ability in grade XI SMA Negeri 1 Kota Pinang Year Learning 2017/2018 begins with the distribution of questionnaire needs analysis. Based on the final results of the calculation can be seen that the questionnaire reading habits of students class XI SMA Negeri 1 Kota Pinang Year Learning 2017/2018 included in the high category. Then followed by the dissemination of reading ability test, after the calculation process is obtained the value of students' reading ability test is in enough category. The results of this reading ability test analysis are not in line with the results of a high categorized questionnaire. Based on that, the researcher develops learning strategy of reading based on KWL strategy.

2. The development of learning strategy based on KWL strategy is effective in improving students' reading ability in grade XI SMA Negeri 1 Kota Pinang Learning Year 2017/2018, where the average value obtained by students before the development process is 17.88 which is in the less category. Furthermore, after development process of learning strategy of reading based on KWL strategy and implementation of learning strategy of reading based on KWL strategy shows that the result of the average score that is owned by students is 31,41 . Thus, the average level of reading ability of grade XI students SMA Negeri 1 Kota Pinang Year Learning 2017/2018 after the development of learning strategy of reading based on KWL strategy is in high category.

\section{References}

1. Arikunto S. Prosedur Penelitian Suatu Pendekatan Praktik. Jakarta: Rineka Cipta, 2006.

2. Buehl Doug. Classroom Strategies for Interactive Learning. Newark, DE: International Reading Association, 2009.

3. Djiwandono Heru. Kemampuan Membaca Teknik Membaca Efektif dan Efisien. Bandung: Angkasa, 2006.

4. Harsono Fuady, dan Saddhono. Pengaruh Strategi Know Want to Learn (KWL) dan Minat Membaca Terhadap Kemampuan Membaca Intensif Siswa SMP Negeri di Temanggung. BASASTRA Jurnal Penelitian Bahasa, Sastra Indonesia, dan Pengajarannya. 2012; 1(1):53-64.

5. Nurgiyantoro Burhan. Penilaian dalam Pengajaran Bahasa dan Sastra. Yogjakarta: BPFE, 2007.

6. Nurgiyantoro Burhan. Statistika Terapan: Untuk Penelitian dan Ilmu-ilmu Sosial. Yogyakarta: Gadjah Mada University Press, 2010.

7. Nurgiyantoro Burhan. Penilaian Pembelajaran Bahasa Berbasis Kompetensi. Yogyakarta: BPFE, 2012.

8. Rahim Farida. Pengajaran Membaca di Sekolah Dasar. Jakarta: Bumi Aksara, 2008.

9. Sapta A. Use of Edmodo in Improving SelfEfficacy. Prosiding Universitas Medan Area, 2018, 1(1).

10. Sapta A. Perbandingan Model Pembelajaran Elaborasi Dengan Model Pembelajaran Advance Organizer, 2018.
11. Skinner $\mathrm{CH}$, Ridge AD. Using the TELLS Prereading Procedure to Enhance Comprehension Levels and Rates in Secondary Students. The University of Tennese. Journal of Psychology in the School, 2010, 481.

12. Sudiana I Nyoman. Membaca. Malang: UM Press, 2007.

13. Sugiyono. Metode Penelitian Kuantitatif dan $R \& D$. Bandung: ALFABETA, 2010.

14. Sukardjo. Kumpulan Materi Evaluasi Pembelajaran. Bandung: Sinar Baru Algesindo, 2008.

15. Sunendar. Sistem Membaca Cepat dan Efektif. Jakarta: Gramedia, 2011.

16. Suyatno. Menjelajah Pembelajaran Inovatif. Sidoarjo: Masmedia Buana Pustaka, 2009.

17. Syafei'ie Imam. Terampil Berbahasa Indonesia I. Jakarta: Depdikbud, 2008.

18. Tarigan Henry Guntur. Membaca Sebagai Suatu Keterampilan Berbahasa. Bandung: Angkasa, 2008.

19. Umamah Nurul. Bahan Ajar. Jakarta: Rineka Cipta, 2012.

20. Uno Hamzah B. Perencanaan Pembelajaran. Jakarta: Bumi Aksara, 2011.

21. Zuchdi Darmiyati. Strategi Peningkatan Kemampuan Membaca Koprehensif. Yogyakarta: UNY Press, 2008. 